\title{
Sciendo
}

DOI: $10.2478 /$ lpts-2019-0021

PHYSICAL AND TECHNICAL ENERGY PROBLEMS

\section{GAS COMBUSTION EFFICIENCY ENHANCEMENT: APPLICATION STUDY OF INTENSE ELESTROSTATIC FIELD}

\author{
O. Krickis ${ }^{1}$, N. Zeltins ${ }^{2}$ \\ ${ }^{1}$ Riga Technical University, \\ Department of Heat and Power Engineering Systems, \\ 6B Kipsalas Str., Riga, LV-1048, LATVIA \\ otto.krickis@gmail.com \\ ${ }^{2}$ Riga Technical University, \\ Faculty of Power and Electrical Engineering, Institute of Power Engineering \\ 12-1 Azenes Str., Riga, LV-1048, LATVIA

\begin{abstract}
A number of international, European Union and Latvian legislative acts have been developed, which regulate the efficiency of gas combustion plants and greenhouse gas emissions in the atmosphere. These legislative acts require the development of new scientifically efficient methods for gas optimal combustion with a minor impact on the environment. In order to achieve such a goal, different methods can be used, but the most efficient is an intensive electrostatic field application to control combustion and harmful emission formation in premixed flames. In the framework of the current study, the authors developed a hybrid burner, which allowed generating an intensive electrostatic field with intensity of more than $1000 \mathrm{kV} / \mathrm{m}$. The study also investigated the impact of such a field on the formation of harmful emissions, including $\mathrm{CO}_{2}$ and flue gas temperature. The empirical results showed that an intensive DC electrostatic field generated inside of the burner had an impact on the flame shape, $\mathrm{CO}_{2}, \mathrm{NO}_{\mathrm{x}}$ emissions and flue gas temperature. In its turn, by applying an intensive pulsating electrostatic field (multivariable experiment) it was possible to achieve the reduction in $\mathrm{NO}_{\mathrm{x}}, \mathrm{CO}$ emissions with a simultaneous increase in flue gas temperature, which was related to combustion process efficiency enhancement.
\end{abstract}

Keywords: electrostatic field, emissions, gas combustion, ionic wind

\section{INTRODUCTION}

In the light of the studies carried out so far and global conclusions of scientists about climate change, a number of international, European Union and 
Latvian legislative acts have been developed, which contribute to the development of novel methods for the combustible gas efficiency enhancement and greenhouse gas emission reduction in the atmosphere. Taking into account the need to ensure national energy independence, with the possibility of fuel diversification or the substitution of different fuel types with equivalent properties, it is particularly important to find technologies for efficient and environmentally friendly use of replacement fuels and to develop technologies that allow for economically efficient operation of combustion plants. Since more than half of all Latvian energy resources are consumed for heating and hot water supply, it is important to analyse energy consumption and the possibilities of reducing harmful emissions related to energy production [1].

The current research is devoted to an in-depth study of the combustion process under the influence of an electrostatic field by conducting laboratory experiments with full-scale equipment that excludes the effects of the surrounding environment on the subject. The results of the research can be used in the project of the Ministry of Economics of the Republic of Latvia "Trends, Challenges and Solutions of Latvian Gas Infrastructure Development (LAGAS)", project No. VPPEM-INFRA-2018/1-0003.

\section{INFLUENCE OF THE ELECTROSTATIC FIELD ON THE COMBUSTION PROCESS}

The stability of combustion and the improvement of the boundaries of combustion are one of the most pressing issues for improvement of modern combustion plants. The use of an electrostatic field in the flame zone provides a solution that is simple in implementation and effective at the same time to change the flame structure and to control the concentration of harmful emissions in the flue gases. The electric field influences the combustion of the flame in three ways: by the thermal effect associated with the conversion of electric energy into heat; by the ionic wind effect; and by the electrically-chemical effect [2]. The electricallychemical effect produces fast electrons, radicals, ionic and induced molecules before the combustion zone, which in turn greatly affects the chemistry of the flame [3][6]. Both laminar and turbulent combustion have shown a combustion improvement under the influence of an electric field (AC and DC) at low electricity consumption compared to the heat input in the combustion chamber. However, there are differences in the result, which make it difficult to identify the main physical phenomenon that contributes to improvement of combustion stabilization [7].

There are a number of chemical ionization reactions that constitute flame ion chemistry. The two most important chemical ionization reactions (1 and 2) are as follows:

$$
\begin{aligned}
& \mathrm{CH}+\mathrm{O} \rightarrow \mathrm{CHO}^{+}+e^{-} ; \\
& \mathrm{CH}^{*}+\mathrm{C}_{2} \mathrm{H}_{2} \rightarrow \mathrm{C}_{3} \mathrm{H}_{3}^{+}+e^{-} .
\end{aligned}
$$


$\mathrm{CH}_{3} \mathrm{O}^{+}$ion concentration in flame is 2-4 times lower compared to $\mathrm{C}_{3} \mathrm{H}_{3}^{+}$ ion. Ion $\mathrm{C}_{3} \mathrm{H}_{3}{ }^{+}$is considered to be the main one in the ion mechanism of the soot formation process. In addition, it should be noted that $\mathrm{CHO}^{+}$is a primary ion in a reaction between an oxidizing atom and a fuel before the combustion process [8].

According to scientists' studies in the reaction zone of the hydrocarbon flame, the chemical ionization process and subsequent reactions are associated with the positive ions of the charged particles $\left(\mathrm{H}_{3} \mathrm{O}^{+}, \mathrm{C}_{3} \mathrm{H}_{3}^{+}, \mathrm{CH}_{3}^{+}, \mathrm{CHO}^{+}\right)$, the formation of negative ions $\left(\mathrm{O}_{2}^{-}, \mathrm{OH}^{-}, \mathrm{O}^{-}, \mathrm{CHO}_{2}^{-}, \mathrm{CHO}_{3}^{-}, \mathrm{CO}_{3}^{-}\right)$and electrons, which interact under the influence of Coulomb force resulting in their transformation and minimising the local electrical potential in which they are located [9], [10].

Using an electric field $(E)$ to influence the combustion process, Lorentz's forces act on charged particles, causing them to accelerate. This calls the drift speed of directly directed charged particles [11]. The positive ions move in the direction of the cathode (lower potential electrode) and repeat the lines of the electric field while the electrons and negative ions move in the opposite direction of the anode (higher potential electrode). This movement of charged particles into a hydrocarbon flame creates an electrical current [12].

In the full-scale test organised by Latvian researchers, the application of an electric field to the industrial boiler DKVR-10-13 was analysed, which resulted in the improvement of heat output by $3.5-8.5 \%$, with an average increase in efficiency of the industrial boiler of $2.8 \%$ at the simultaneous thermal $\mathrm{NO}_{\mathrm{x}}$ reduction in the range of $15-20 \%$ [13].

\section{RESEARCH METHODOLOGY}

In the framework of the current research, the investigational process was divided into two stages in order to identify the different type of the equipment layout and electrostatic field impact on the combustion process parameters and flue gas composition changes, which depend on one or more experimental factors.

The first stage of the research is based on gathered data from the previous study [14]. The experimental equipment included specially designed combustion chamber and burner (hereinafter - hybrid burner), an electric field-generator laboratory-type transformer with a small voltage adjustment step, combining all of these parts with step-up high-voltage transformer with a high-voltage multiplier that simultaneously performed a rectification function. This stage of the research is based on the determination of changes in the composition of the flue gas, depending on the voltage of the DC source used, which was applied to the hybrid burner. The factor to be controlled for this experiment is the DC voltage, while the response is the concentration and temperature values of the components of the flue gas, which in total constitute the seven parameters. The limit of the variable factor is the voltage range from $0 \mathrm{~V}$ to $2200 \mathrm{~V}$. The study was based on one factor variation at nine levels with manually performed distribution of levels.

In the framework of the second stage of the research, the authors performed the analysis of flue gas composition and flue gas temperature change of LPG (propane molar fraction 0.92) combustion process depending on the three external 
variable factors: 1 - pulsating current (voltage); 2 - pulsating current frequency (switching frequency); 3 - ozone generation equipment operating interval (duration of the relay switch). An analysis of the interactions among the three variable factors was performed for each factor at ten levels. According to the assessment of the experiment design, the method developed by Latvian scientist Dr.sc.ing. V. Eglājs -

Latin hypercube, which refers to the space-filling experiments, was chosen.

\section{EXPERIMENTAL EQUIPMENT LAYOUT}

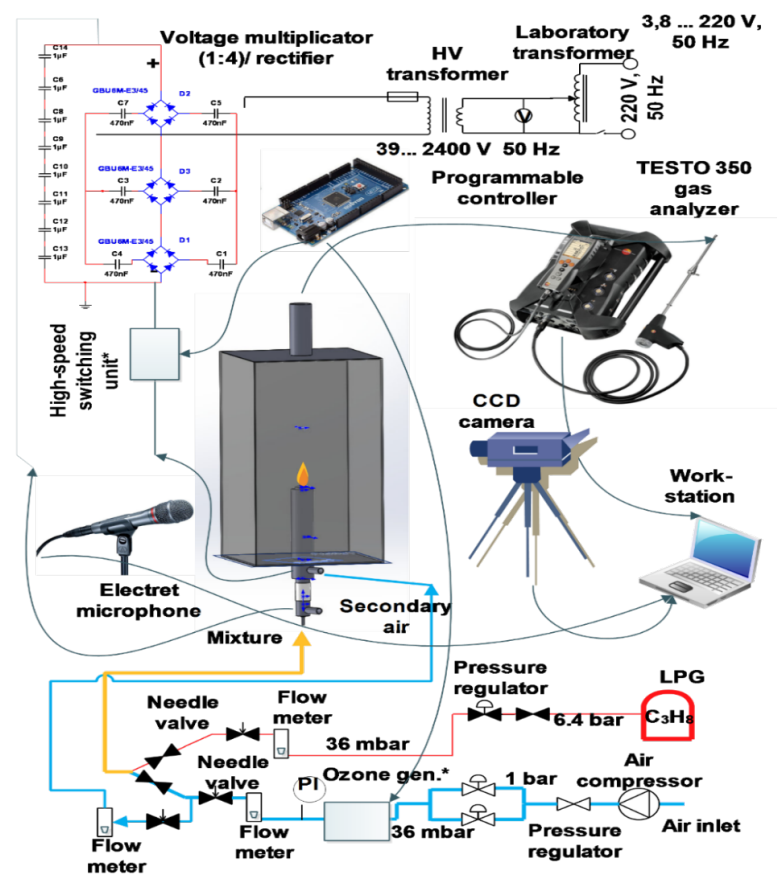

Fig. 1. Scheme of experimental equipment for the first and second stages of the research.

The experimental equipment used for the research consists of a number of individual components whose operation is synchronised in a single process and allows for the analysis of the measured data for a single mode. The experimental equipment (Fig. 1) has the following components: for flame shape visual analysis a monochrome CCD camera and high-speed camera were used, an industrial flue gas analyser (TESTO 350), a flame-sound recording device with a sound amplifier, a voltage regulation unit, a voltage multiplication and a current rectification unit, a high-voltage ignition unit, an air supply compressor, an air flow regulation and adjustment unit, an accounting unit, a fuel gas supply unit, a gas flow regulation and adjustment unit, a flow mixing unit, a combustion chamber with two-stage air flow decomposition and workstation for data processing. Apart from these components, a specially designed ozone gas generation device (including the Generation Time Control Module) was used during the second stage of the study. For the second stage of the research, a specially designed high-speed switching unit (with a high-voltage MOSFET type transistor) and an electronic four-channel oscilloscope were used. 


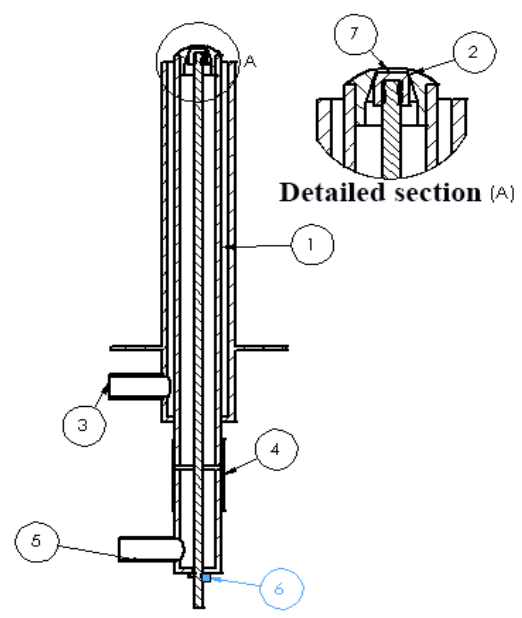

Fig. 2. Section view of the hybrid burner with element numbering:

1 - Air/Gas supply channel; 2 - Flow control unit/external electrode;

3 - Secondary air supply channel; 4 - Dielectric PVC sleeve; 5 - Air/Gas supply channel;

6 - Flow adjustment rod (burner-centring rod); 7 - profiled cap of the burners.

A hybrid burner (Fig. 2) was designed and developed for the research. It was made of stainless steel and used to generate an electric field by connecting a highvoltage source to it. For electric field generation, the burner construction included a number of dielectric elements to ensure the separation of the outer casing of the burner from the burner core, which in turn played the role of both the air/combustible gas mixture supply control and the flame shape adjustments function. The bottom and core of the burner were insulated from the upper burner shell with a PVC insert and dielectric (textolite) centring rings. The outer diameter of the centring rings is equal to the inner diameter of the burner's primary flow channel, while for the provision of flow in it 8 holes with a diameter of $3 \mathrm{~mm}$ were made. The geometry of the upper part of the core (cap) shall be closely adapted to the geometry of the upper part of the outer shell of the burner, thereby ensuring the radial discharge of the mixture into the combustion zone. The burner was designed to supply secondary air to the combustion zone (inside the combustion chamber) through a separate channel around the primary mixture channel. Such an equipment layout and air supply method allowed analysing the premixed flame combustion, which was constructively equivalent to the fullscale industrial burners' performance indicators.

The hybrid burner design developed during the research (Fig. 2) provided an effective intensity of the electrostatic field of $1140 \mathrm{kV} / \mathrm{m}$, which several times exceeded the parameters of the equipment achieved in the studies of other scientists [15], [16].

\section{RESEARCH RESULTS}

The first stage of the research was based on the analysis of the impact of the intensive DC electrostatic field on the combustion of liquefied propane gas, including visual recording of the flame front, the analysis of changes in flue gas composition, as 
well as the treatment of the thermo-acoustic signal using Fast Fourier Transformation (hereinafter - FFT) method.

At the first and second stages of the research, a combustion chamber of the same design was used, whereby, in addition to direct measurements, a numerical analysis of the combustion process was carried out using a simulation method based on realistic GRIMECH 3.0 and SAN DIEGO chemical-kinetic mechanisms in CHEMKIN-PRO environment. For this numerical analysis, actual recorded air and gas flows were used.

The results of the numerical analysis of the combustion process showed that the burner constructed within this research was capable to secure propane burning within a wide range of equivalence factors from to (determined by the proportion of fuel/air in the reactor zone), which was equivalent to the propane molar fraction range .

\subsection{Results of the First Stage of the Research}

The goal of the first stage of the research was to determine the effects of intense DC electrostatic field on gaseous fuel combustion, flame shape variation and flue gas formation. Under these conditions, the voltage range was increased, keeping all rest parameters unchanged. At this stage of the study, the fuel input capacity was $0.17 \mathrm{~kW}_{t h}$. As a reference point for flame-shape comparison, the authors used flame visual information taken in electrostatic free conditions. To determine the deviations of flame shape, the pictures were supplemented with the coordinates of the pixels. The maximum flame-consumed current was, when a positive potential was connected to the burner-centering rod. According to the voltage-current characteristics (Fig. 3), it is concluded that the consumed current significantly increases starting from $1300 \mathrm{~V}$, when effect of ionic wind appears. These results have a good correlation with the picture set of flame-shape changes (Fig. 4).

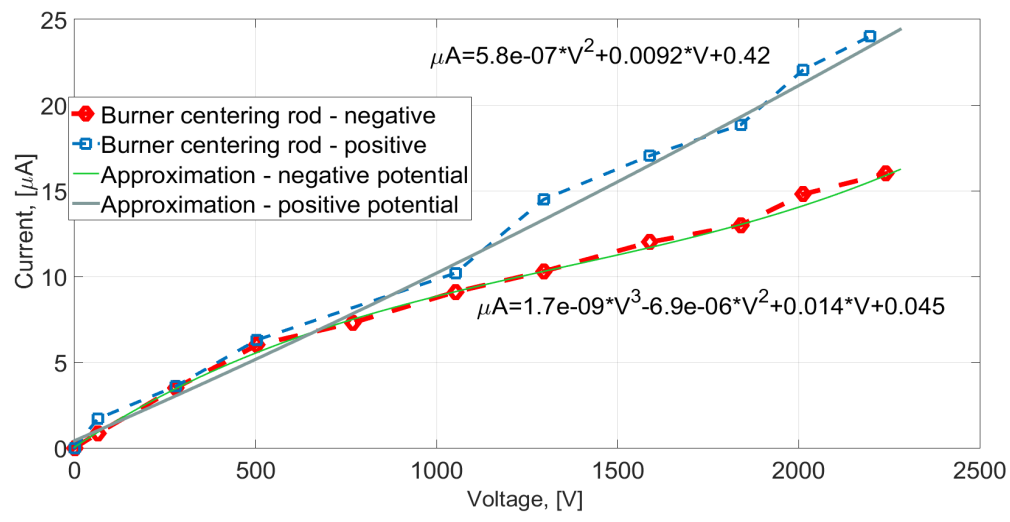

Fig. 3. Voltage-current characteristics of the experimental equipment.

According to the flame shape and length change analysis, it can be concluded that the electrostatic field impact on the flame shape with the negative connected potential to the burner-centring rod is minimal. This is due to a relatively small 
surface area $\left(12 \mathrm{~mm}^{2}\right)$ of the centring rod, which performed the function of the electrode. Taking into account that the electrode of the burner-centring rod was located below the root of the flame, the drift of the positive ions from the flame front to the negative electrode was practically unattainable. These results showed that such an arrangement of the electrode and the connection of a DC source contributed to a minimal change in flame shape compared to the combustion mode without the use of an electrostatic field.

According to the graphical results with the positive connected potential to the burner-centring electrode, it is apparent that starting from $400 \mathrm{~V}$ the length of the flame kernel is decreasing, while starting from $700 \mathrm{~V}$ there is an extension of the root of the flame. This could be explained with a positive ion drift to the burner shell, to which the negative potential was attached. The impact of the electrostatic field (Fig. 4) on the change in flame length is significant and its contraction is $24 \%$ compared to the burning mode without the use of an electrostatic field. The flame root extension, however, is $27 \%$. These results show that an electrode with a diameter of 2.5 times larger than the flame diameter constitutes a proportional reduction in the length of the flame kernel and an extension of the root of the flame.
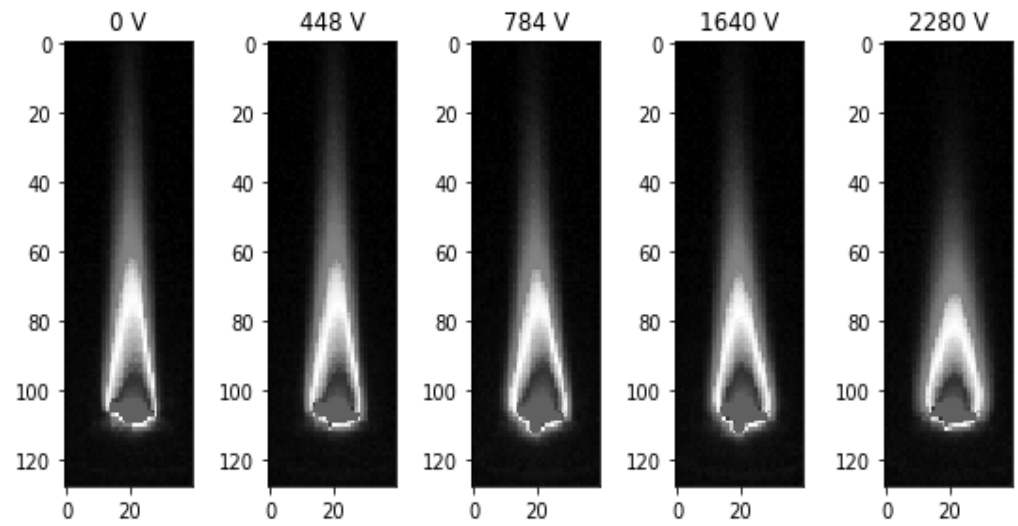

Fig. 4. Graphical comparison of the flame shape in the voltage range $0-2280 \mathrm{~V}$ when the burnercentring rod was used as an anode and the burner shell as a cathode.

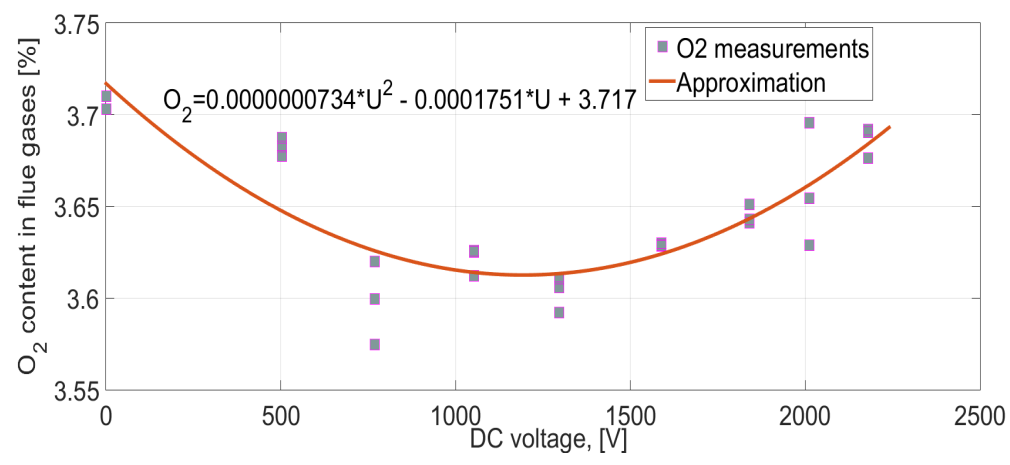

Fig. 5. The oxygen content in the flue gases under intense electrostatic field conditions, when the burner shell was used as a cathode. 
In the framework of the research, the authors performed the analysis of the flue gas composition using a specially designed inspection point in the combustion chamber. The sampling point was created at the top of the vertical wall of the combustion chamber, which ensured the placement of the flue gas analyser TESTO 350 measuring probe perpendicular to the flue gas flow. The analysis covered the following parameters: percentage of oxygen in the flue gases $\mathrm{O}_{2}$, concentration of carbon monoxide in the flue gases $\mathrm{CO}$, carbon dioxide in the flue gases $\mathrm{CO}_{2}$, concentration of nitrogen oxide in the flue gases $\mathrm{NO}$, concentration of nitrogen dioxide in the flue gases of $\mathrm{NO}_{2}$, concentration of nitrogen oxides in the flue gases NOx and flue gas temperature.

When the burner shell was used as an anode, an increase in oxygen content in the flue gases was observed, ranging from $4.14 \%$ to $4.35 \%$. While in the second part of the experiment, when the burner shell was used as a cathode, the oxygen content in the voltage range $0-1300 \mathrm{~V}$ was reduced parabolically from $3.72 \%$ to $3.6 \%$. From $1300 \mathrm{~V}$ oxygen content increased to its original state (Fig. 5).

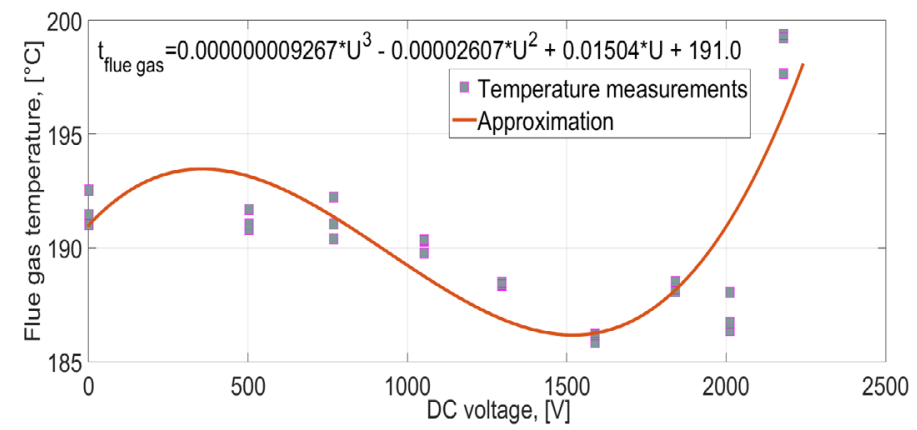

Fig. 6. Flue gas temperature under intense electrostatic field conditions, when the burner shell was used as a cathode.

Temperature of flue gas is directly proportional to the flame combustion temperature, up to which determination of the flame temperature changes was carried out based on flue gas temperature registration via a flue gas analyser probe with an integrated thermocouple.

According to the measurement results, when the burner shell was used as an anode, the temperature of flue gas evenly descended, which correlated with the oxygen content change in the flue gas. At the maximum electrostatic field intensity, a decrease in the flue gas temperature of $7.5^{\circ} \mathrm{C}$ was noted, which was $3.5 \%$ compared to the combustion mode without the use of an electrostatic field. In the experiment with a positive-connected potential to the burner-centring rod (the burner shell was used as a cathode), it was found that starting from $1300 \mathrm{~V}$, the temperature of the flue gases began increasing parabolically, reaching its peak $\left(199{ }^{\circ} \mathrm{C}\right)$ at a maximum electrostatic field strength of $1140 \mathrm{kV} / \mathrm{m}$ (Fig. 6).

The maximum specific increase in nitrogen oxides $\left(\mathrm{NO}_{\mathrm{x}}\right)$ concentration was $10 \%$ at $525 \mathrm{kV} / \mathrm{m}$ electrostatic field intensity (Fig. 7), when the burner shell was used as an anode. In these conditions, the maximum reduction in the concentration of carbon monoxide (CO) was $35 \mathrm{mg} / \mathrm{m}^{3}$, which was equivalent to a specific reduction of $5.2 \%$. 

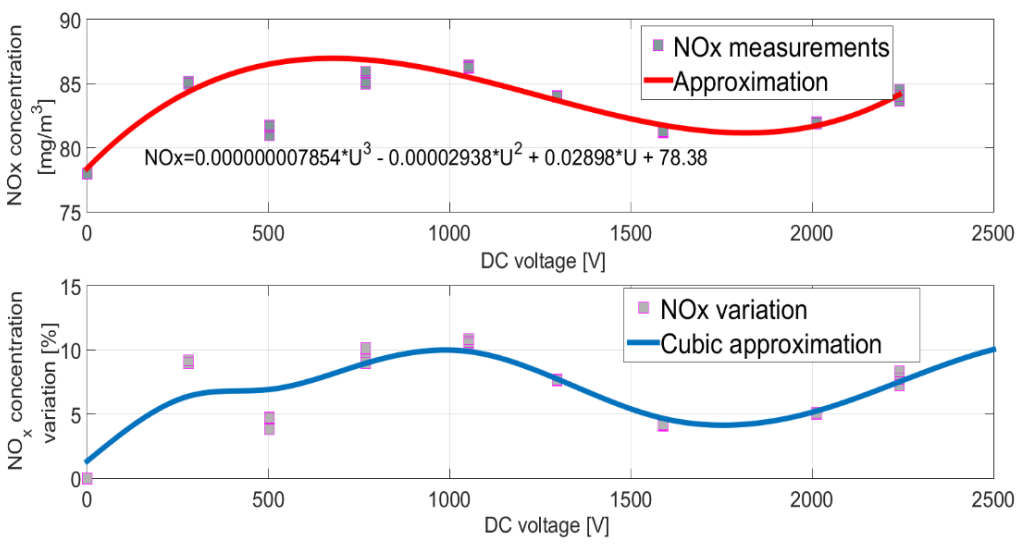

Fig. 7. Nitrogen oxide concentration variation under intense electrostatic field conditions, when the burner shell was used as an anode.
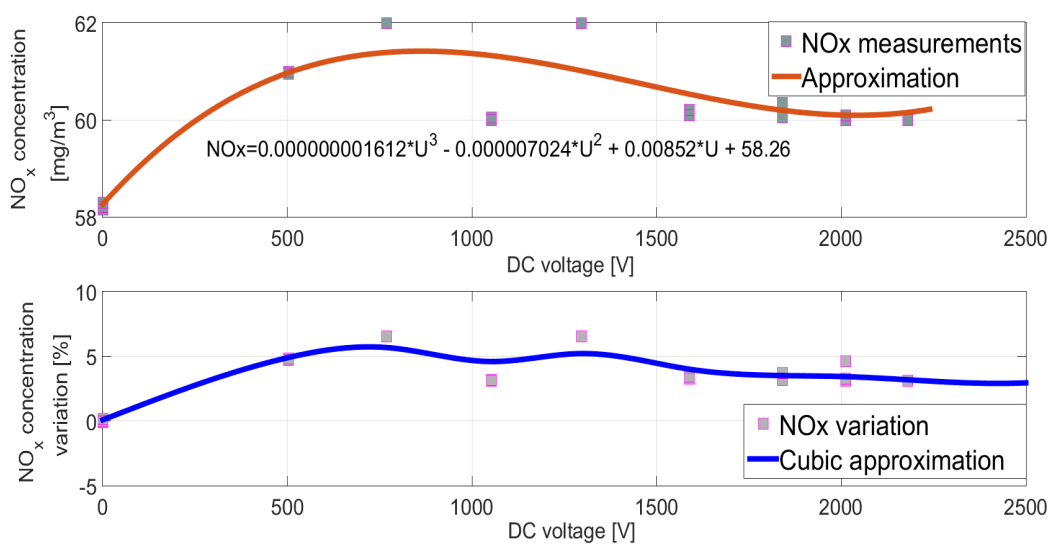

Fig. 8. Nitrogen oxide concentration variation under intense electrostatic field conditions, when the burner shell was used as a cathode.
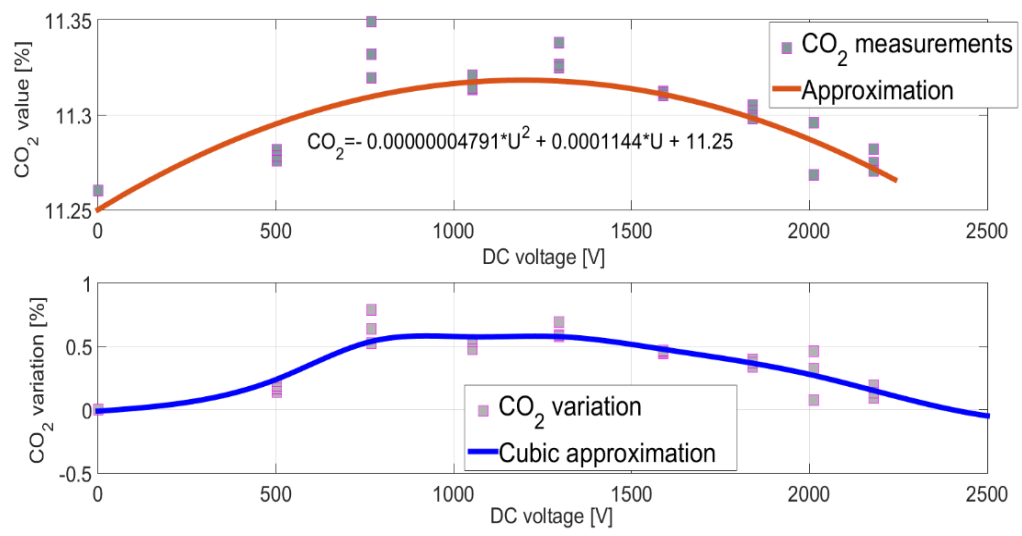

Fig. 9. Carbon dioxide concentration variation under intense electrostatic field conditions, when the burner shell was used as a cathode.

However, when the burner shell was used as a cathode and the burner-centring rod as an anode, the maximum increase in $\mathrm{NO}_{\mathrm{x}}$ emissions was $5.3 \%$ (Fig. 8), while the 
reduction in $\mathrm{CO}$ emissions reached $7.1 \%$ compared to the baseline. An improvement in the combustion process was found in an experiment with a positive connected potential to a burner-centring rod and simultaneous electrostatic field intensity of $525 \mathrm{kV} / \mathrm{m}$, carbon dioxide $\left(\mathrm{CO}_{2}\right)$ in the flue gases increased by $0.07 \%$, which was equivalent to a specific increase of $0.6 \%$ (Fig. 9).

The flame thermo-acoustic signal under the influence of the electrostatic field was analysed using the Electret type microphone for the sound range 0.02-16 kHz, which was placed at the same level with the average flame plane. Based on the processed acoustic signal results in the full frequency range $0.02-25 \mathrm{kHz}$, it can be concluded that no change in the amplitude of the acoustic flame signal is observed starting from $2 \mathrm{kHz}$. The fundamental recorded harmonic according to the FFT analysis of the acoustic signal is $150 \mathrm{~Hz}$. It should be noted that the same fundamental harmonic was recorded at both variations of the DC polarity connection.

The FFT analysis shows that connection of DC positive potential to the burnercentring rod and the simultaneous connection of negative potential to the burner shell has a significant impact on the flame acoustic signal (noise) enhancement. According to the comparison of signal amplification at peak voltage $(2280 \mathrm{~V})$, the signal amplitude is 115 times higher compared to the baseline.

\subsection{Results of the Second Stage of the Research}

The goal of the second stage of the research was to determine the effects of intense pulsating electrostatic field including multivariate interaction on the composition of flame combustion products. The multivariate impact analysis was based on the analysis of the variation in the composition of the flue gases, depending on three factors: pulsating current voltage; pulsating current frequencies; switching intervals for the ozone generating device.

The maximum pulsating current voltage was limited to $900 \mathrm{~V}$, a pulsating current frequency of $10,000 \mathrm{~Hz}$ and an operating interval of the ozone generating device of $2000 \mathrm{~ms}$. Taking into account assessment of the safety and ozone leakage aspects, the ozone generating device was integrated into the air flow channel before mixing with the combustion gas.

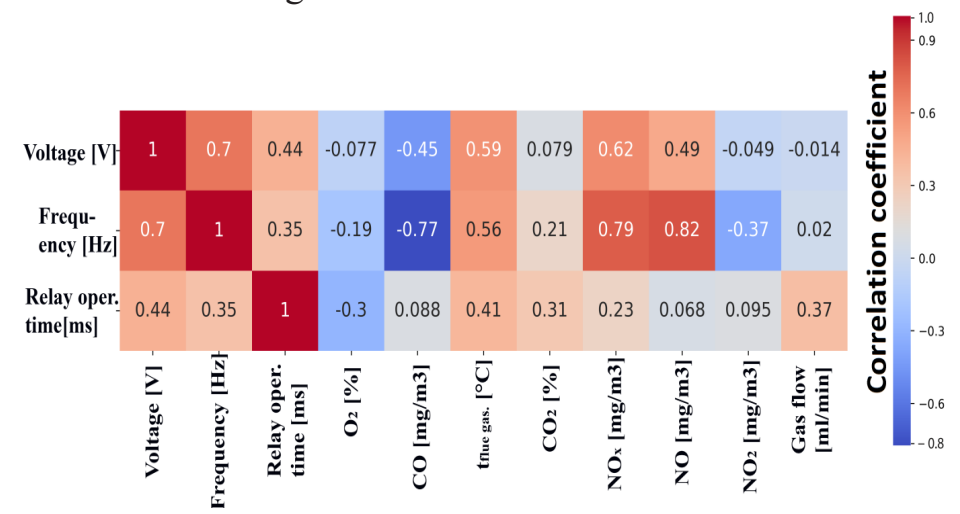

Fig. 10. Multivariate correlation heat map for an experiment with negative pulsating current potential connected to the burner-centring rod. 
For a three-factor cross-impact analysis on a number of registered responses, a cross-correlation factor was established for each variable and each response. The calculated linear correlation factors for each factor and response were compiled in a graphic form using the heat map method. The results of this interaction analysis are presented in Figs. 10 and 11.

According to the results presented in Fig. 10, it can be concluded that none of the factors justified a linear correlation with the oxygen content in the flue gases. However, the study detected a significant impact of the pulsating current frequency on the change in carbon monoxide (CO) concentration. These results showed that a sequential substitution of oxygen by ozone gas using a negative-connected pulsating potential to the burner-centring rod did not have an impact on the measurements. It should be noted that this multivariate experiment showed the impact of the set frequency of a pulsating current on $\mathrm{NO}_{\mathrm{x}}$ and $\mathrm{NO}$ emissions.

In an experiment with a positive pulsating current potential, which was connected to the burner-centring rod (Fig. 11), a good correlation was found between all three influence factors on the flue gas temperature and a change in $\mathrm{NO}_{\mathrm{x}}$ concentration. The obtained results refer to the voltage range up to $900 \mathrm{~V}$. The heat map of the correlation factors showed the existing relationship between the voltage and the concentration of $\mathrm{NO}_{2}$ in the flue gases, as well as between the frequency of the pulsating current and the concentration of $\mathrm{NO}_{2}$ in the flue gases. In addition, the change in $\mathrm{CO}$ concentration in the flue gases was mostly dependent on the conditions with increased voltage.

The assessment of the temperature change in the flue gases, depending on three factors, proved the high potential of the pulsating current and partial ozone gas application. Each step-up level of each factor increased the temperature of the flue gases. In addition, the results of the $\mathrm{CO}$ emission measurements testified about more complete combustion and better heat release from the flame.

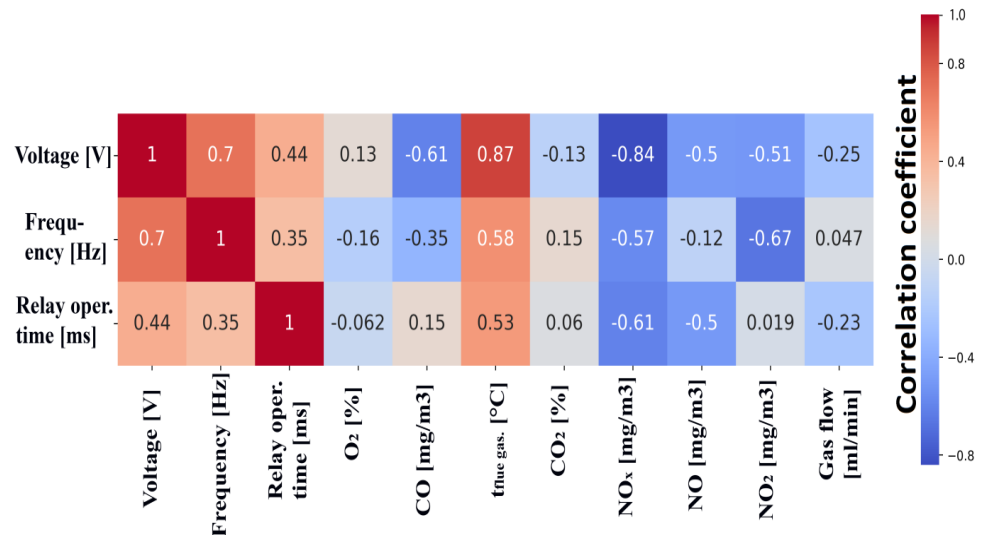

Fig. 11. Multivariate correlation heat map for experiment with positive pulsating current potential connected to the burner-centring rod.

On the basis of these results, it is concluded that the intensive electrostatic field of the pulsating current source, its pulse frequency, and the partial substitution of the oxidizer with a more active oxidising agent (ozone) improve the propane flame combustion and the heat release from the flame, which can be demonstrated by an 
increase in the temperature of the flue gases. In the framework of the experiment, it was found that pulsating current voltage, pulsating frequency and ozone as oxidizer had a direct effect on the rapid $\mathrm{NO}_{\mathrm{x}}$ formation process rather than on thermal $\mathrm{NO}_{\mathrm{x}}$.

\section{CONCLUSIONS}

The proposed method, using intensive DC and pulsating electrostatic field, for the gaseous fuel combustion enhancement allows increasing the efficiency of the combustion process and controlling the formation of harmful emissions in the atmosphere.

The study experimentally proved the intensive DC electrostatic field impact on flame shape changes, which began at intensity of $200 \mathrm{kV} / \mathrm{m}$. At an electrostatic field intensity of the $1140 \mathrm{kV} / \mathrm{m}$ flame length reduction was $24 \%$ and the extension of the flame root $-27 \%$. According to the results, the intensive DC electrostatic field increased $\mathrm{NO}_{\mathrm{x}}$ emissions by $5.3 \%$ on average, while the reduction in $\mathrm{CO}$ emissions reached $7.1 \%$ compared to baseline. Experimentally analytical results showed that the intensive DC electrostatic field had an influence on the thermo-acoustic effect of the flame, significantly increasing the amplitude of the harmonics. The results suggested that the electrostatic field did not contribute to the acoustic resonant effect of the flame.

The results of the research also demonstrated that the pulsating current electrostatic field, combined with a sequential substitution of oxidizer (free oxygen and three atomic oxygen), allowed achieving $\mathrm{NO}_{\mathrm{x}}$ emission reduction and was capable to increase the temperature of flue gases indicating the intensification of heat exchange.

The developed method can be adjusted to different gaseous fuels, thus ensuring better combustion capabilities and lower impact on the atmosphere. Moreover, it also allows controlling the geometry of flame, which can be used in order to reduce maintenance costs of the gas combustion equipment.

\section{ACKNOWLEDGEMENTS}

The research has been supported by the National Research Programme, project "Trends, Challenges and Solutions of Latvian Gas Infrastructure Development" (LAGAS) (No. VPP-EM-INFRA-2018/1-0003).

\section{REFERENCES}

1. Davis, A., Mikelsons, K., Puikevica-Puikevska, I., Silantjeva, I., Zebergs, V., \& Zeltins, N. (2007). The methods of analysis for raising the energy efficiency and the reduction of greenhouse gases. In: 27th USAEE/IAEE North American Conference: Developing \& Delivering Affordable Energy in the 21st Century (pp. 24-25), USA, Houston, Texas, Book of extended abstracts.

2. Zhang, Y., Wu, Y., Yang, H., Zhang, H., \& Zhu, M. (2013). Effect of high-frequency alternating electric fields on the behaviour and nitric oxide emission of laminar nonpremixed flames. Fuel, 109, 350-355, DOI: https://doi.org/10.1016/j.fuel.2012.12.083 
3. Ombrello, T., Won, S.H., Ju, Y., \& Williams, S. (2010). Flame propagation enhancement by plasma excitation of oxygen. Part I: Effects of $\mathrm{O}_{3}$. Combustion and Flame, 157(10), 1906-1915, DOI: https://doi.org/10.1016/j.combustflame.2010.02.005

4. Ombrello T., Won, S.H., Ju, Y., \& Williams, S. (2010). Flame propagation enhancement by plasma excitation of oxygen. Part II: Effects of $\mathrm{O}_{2}\left(\mathrm{a}^{1} \Delta \mathrm{g}\right)$. Combustion and flame, 157(10), 1916-1928, DOI: https://doi.org/10.1016/j.combustflame.2010.02.004

5. Sun, W., Uddi, M., Ombrello, T., Won, S.H., Carter, C., \& Ju, Y. (2011). Effects of nonequilibrium plasma discharge on counterflow diffusion flame extinction. Proceedings of the Combustion Institute, 33(2), 3211-3218, DOI: https://doi.org/10.1016/j. proci.2010.06.148

6. Sun, W., Uddi, M., Won, S.H., Ombrello, T., Carter, C., Ju, Y. (2012). Kinetic effects of non-equilibrium plasma-assisted methane oxidation on diffusion flame extinction limits. Combustion and Flame, 159(1), 221-229, DOI: https://doi.org/10.1016/j. combustflame.2011.07.008

7. Belhi, M., Domingo, P., \& Vervisch, P. (2010). Direct numerical simulation of the effect of an electric field on flame stability. Combustion and Flame, 157(12), 2286-2297, DOI: https://doi.org/10.1016/j.combustflame.2010.07.007

8. Fialkov, A. B., Kalinich, K. Y., \& Fialkov, B. S. (1992). Experimental determination of primary ions in flame. Twenty-fourth Symposium on Combustion/The Combustion Institute. Elsevier, 785-791, DOI: https://doi.org/10.1016/S0082-0784(06)80096-20

9. Goodings, J. M., Bohme, D. K., \& Ng, C. W. (1979). Detailed ion chemistry in methane oxygen flames. I. Positive ions. Combustion and Flame, 36, 27-43, DOI: https://doi. org/10.1016/0010-2180(79)90044-0

10. Goodings, J. M., Bohme, D. K., \& Ng, C. W. (1979). Detailed ion chemistry in methane oxygen flames. II. Negative ions. Combustion and Flame, 36, 45-62, DOI: https://doi. org/10.1016/0010-2180(79)90045-2

11. Bisetti, F., \& El Morsli, M. (2012). Calculation and analysis of the mobility and diffusion coefficient of thermal electrons in methane/air premixed flames. Combustion and Flame, 159(12), 3518-3521, DOI: https://doi.org/10.1016/j.combustflame.2012.08.002

12. Hu, J., Rivin, B., \& Sher, E. (2000). The effect of an electric field on the shape of coflowing and candle-type methane-air flames. Experimental Thermal and Fluid Science, 21(1-3), 124-133, DOI: https://doi.org/10.1016/S0894-1777(99)00062-X

13. Barmina, I., Purmalis, M., Valdmanis, R., \& Zaķe, M. (2016). Electrodynamic control of the combustion characteristics and heat energy production. Combustion Science and Technology, 188(2), 190-206.

14. Krickis, O. (2017). Effect of electric field in the stabilized premixed flame on combustion process emissions. In: IOP Conference Series: Materials Science and Engineering. IOP Publishing, 251, 1-5, DOI: https://doi.org/10.1088/1757-899X/251/1/012116

15. Gan, Y., Luo, Y., Wang, M., Shi, Y., \& Yan, Y. (2015). Effect of alternating electric fields on the behaviour of small-scale laminar diffusion flames. Applied Thermal Engineering, 89, 306-315, DOI: https://doi.org/10.1016/j.applthermaleng.2015.06.041

16. Belhi, M., Domingo, P., \& Vervisch, P. (2009). Effect of electric field on flame stability. Proc. of the European Combustion Meeting, 1, 1-6. 


\title{
GĀZES DEGŠANAS EFEKTIVITĀTES UZLABOŠANA: INTENSĪVĀ ELEKTROSTATISKĀ LAUKA LIETOŠANAS PĒTİJUMS
}

\author{
O. Krickis, N. Zeltiņš \\ Kopsavilkums
}

Rakstā apskatīta zinātniski pamatota metode gāzveida kurināmā optimālākai sadegšanai, pielietojot intensīvu elektrostatisko lauku. Pētījuma ietvaros tika izstrādāta un aprobēta unikālās konstrukcijas gāzes sadedzināšanas iekārta, kas l̦auj generēt elektrostatisko lauku ar intensitāti, pārsniedzot $1000 \mathrm{kV} / \mathrm{m}$. Rezultātā tika izpētīta līdzstrāvas, kā arī pulsējošās strāvas elektrostatiskā lauka ietekme uz gāzes kurināmā degšanu, īpaši vērtējot liesmas formas izmaiņas, dūmgāžu sastāva variāciju un degšanas efektivitāti.

12.07.2019. 